\title{
BATTERED WOMEN - IN FEAR OF LUC'S SHADOW
}

\section{Susan Edwards ${ }^{*}$}

\section{INTRODUCTION}

Recent critique of the law regulating spousal homicide has centred on the obstacles frequently encountered by female defendants: inter alia their relative inability, compared to male counterparts to avail themselves of defences to homicide; self-defence and provocation. This differential experience arises in consequence of the law's construction of the partial defence of provocation, the complete defence of self-defence and the rules governing evidence and admissibility distinguishing fact from law. In this article, the boundaries set by legal rules which distinguish law from fact, including rules of evidence, especially as this distinction is affected by gender, will be examined. ' It is intended to consider the taken for granted and absolute distinction between common sense and expert opinion, and to consider what kinds of behaviour constitute provocative conduct, to consider how far this reflects all human or primarily the male experience and to examine how far this becomes reconstituted as the core of legal reasoning. It is proposed to consider how the experience of women especially the reaction of battered women in self-defence, ${ }^{2}$ provocation ${ }^{3}$ and diminished responsibility ${ }^{4}$ becomes constituted either as specialist knowledge, and thereby bound by rules circumscribing the admissibility of expert testimony to specific facts, or else is constituted as common sense

* Buckingham School of Law, the University of Buckingham.

' J.M.Conley \& W.M.O'Barr, Rules versus Relationships (The University of Chicago Press, 1990); N.R.Cahn, "The Looseness of Legal Language: The Reasonable Woman Standard in Theory and in Practice" 77 Cornell L.Rev. 1398-1434 (1992).

${ }^{2}$ Criminal Law Act 1967 s.3(1).

${ }^{3}$ Homicide Act 1957 s.3.

${ }^{4}$ Homicide Act 1957 s.2. 


\section{DENNING LAW JOURNAL}

knowledge and thereby excluding experts to speak to it. With the consequence that where such facts are unknown to jurors, in the absence of an ascription of mental illness, women's access to the legal defences is eroded. Some of these considerations have been explored by inter alia $\mathrm{O}^{\prime}$ Donovan, ${ }^{5} \mathrm{Horder}^{6}$ and McColgan. ${ }^{7}$ This article extends this debate to include an assessment of recent case law and case management in the light of Thornton (No.2), ${ }^{8}$ Morhall, ${ }^{9}$ Luc Thiet Thuan v. R., ${ }^{10}$ and Parker ${ }^{11}$ for those defending battered women who kill to include consideration of the retrial of Sarah Thornton, ${ }^{12}$ and the cases of Sangha ${ }^{13}$ and Hobson. ${ }^{14}$ The "rule" of Lord Goff in Luc holds that only those characteristics relating to the gravity of the provocation are likely to be relevant whilst characteristics relating to loss of self-control are not. Whilst a decision of the Privy Council, in the light of the approach of the Court of Appeal in Parker, ${ }^{15}$ its authority is unresolved. This divide re-affirms the earlier reasoning in Lesbini ${ }^{16}$ which excluded bad-temperedness or pugnacity as a notional characteristic under the limb of the objective test, precisely on the grounds that it went to the defendant's loss of self-control, re-affirming the principles enunciated in Welsh:

${ }^{5}$ K.O'Donovan, "Law's Knowledge: The Judge, The Expert, The Battered Woman, and Her Syndrome" (1993) 20 Journal of Law and Society 427-437.

${ }^{6}$ J.Horder, Provocation and Responsibility (Clarendon Press, 1992).

'A.McColgan, "In Defence of Battered Women Who Kill" (1993) 13 O.J.L.S. 508-529.

${ }^{8}$ [1996] 2 All E.R. 1023 (C.A.).

${ }^{9}$ [1995] 3 All E.R. 659.

${ }^{10}$ [1996] 2 All E.R. 1033 (P.C.).

${ }^{11}$ [1997] Crim.L.Rev.760.

${ }^{12}$ Thomton Retrial, Oxford Crown Court, 13th.-24th.May, 1996. The author attended the retrial and analysis is based on contemporaneous notes of the hearing.

${ }^{13}$ [1997] l Cr.App.R.(S) 202.

${ }^{14}$ [1997] Crim.L.Rev. 759; The Times 25th.May, 1997; The Independent 6th.June, 1997 (Transcript: Smith Bernal).

${ }^{15}$ Supra.n.11.

${ }^{16}$ [1914] 3 K.B. 1116 (C.A.). 


\section{BATTERED WOMEN - IN FEAR OF LUC'S SHADOW}

"there must exist such an amount of provocation as would be excited by the circumstances in the mind of the reasonable man, and so as to lead the jury to ascribe the act to the influence of that passion."

Recent efforts towards inclusion of battered woman syndrome as a notional characteristic within a defence of provocation demonstrated in the cases of Thomton (No.2) ${ }^{18}$ and Ahluwalia ${ }^{19}$ is now uncertain. How will courts interpret $L u c$ and will it make any difference? Whatever the "Goffian" schema, developed in Morhall ${ }^{20}$ and $L u c{ }^{21}$ which determines which characteristics are relevant and which are not, for the battered woman, the violence and the threat of and potential for violence, are realities enmeshed in her knowledge and perception and determine her strategy for survival. In this case then, the "characteristic" is not merely to be constructed as a lowered threshold of self-control induced in a person following years of abuse, but instead is a "characteristic" of intimate knowledge arising as a result of a habituated experience, grounded in observation and prediction. The notional characteristic of battered woman experience includes both these facets.

\section{LEGAL RULES}

(a)The dogma of a closed system: legal relevance and exclusion

The traditional approach to the metaphysics of law has regarded legal rules as part of a closed autonomous system ${ }^{22}$ where law's proper concern is with what is determined by judges who declare law. The belief in the orthodoxy of an unadulterated, entombed and sealed law, focusing "over deterministically" on law as a discrete and isomorphic system with inherently neutral rules, is all

${ }^{17}(1869) 11$ Cox 336 at 338 .

${ }^{18}$ Supra.n.8.

${ }^{19}$ [1992] 4 All E.R.889.

${ }^{20}$ Supra.n.9.

${ }^{21}$ Supra.n.10.

${ }^{22}$ V.Kerruish, Jurisprudence as Ideology (Routledge, 1991) at 5; A.Hunt, "The Critique of Law: What is 'Critical' about Critical Legal Theory?" in Critical Legal Studies, P.Fitzpatrick \& A.Hunt (eds.) (Basil Blackwell, 1987) at 10. 


\section{DENNING LAW JOURNAL}

pervasive. Law's rules, relevances, conventions and constructs, as if religious hermeneutic dogma and omnipotent truth, are considered beyond question, unassailable and definitive. Chailenges to this hallowed orthodoxy have centred on destabilising the credo that judges merely declare law and that legal knowledge is given. "The common law is not a brooding omnipresence in the sky." 24 Such challenges have come from within and without.
"Those with a taste for fairy tales seem to have thought that in some Aladdin's case there is hidden the Common Law in all its splendour and that on a judge's appointment there descends on him the knowledge of magic words Open Sesame. Bad decisions are given when the judge has muddled the password and the wrong door opens. But we do not believe in fairy tales any more." 25

The emergence of legal principles is considered the product of the wisdom of judges, who divine law's "truth." Yet in truth judges are merely "reactive agents" who accept or reject the proactive argument counsel put before them. ${ }^{26}$ Indeed, in recent trials of battered women who kill, it has been those challenges to existing legal principles made by defence counsel which have set the agenda(s) for the development of law in this area. In this sense, Lord Justice Beldam, Lord Chief Justice Taylor, Lord Justice Hirst and Lord Steyn, whilst ultimate arbiters of law's "truth," authenticate or invalidate the legal argument on what traits can be considered as notional characteristics within the objective test put before them by Lord Gifford Q.C. in Thomton, ${ }^{27}$ Geoffrey Robertson Q.C. in Ahluwalia, ${ }^{28}$ Helen Grindrod Q.C. in Humphreys, ${ }^{29}$ and Michael

${ }^{23}$ R.Cotterell, "Law's Community: Legal Theory and the Image of Legality" (1992) 19 Journal of Law and Society 405 at 414.

${ }^{24}$ Southern Pacific Co. v. Jensen 244 U.S. 205 at 222 per Holmes J.(1917).

${ }^{25}$ Lord Reid in S.Lee, Judging Judges (faber \& faber, 1989) at 3.

${ }^{26}$ P.Devlin, The Judge (O.U.P., 1979) at pp.12-13.

${ }^{27}$ [1992] 1 All E.R. 306.

${ }^{28}$ Supra.n. 19.

${ }^{29}$ [1995] 4 All E.R. 1008. 


\section{BATTERED WOMEN - IN FEAR OF LUC'S SHADOW}

Mansfield Q.C. in Thornton (No.2) ${ }^{30}$ Confirming that legal knowledge is dependant upon challenges to law's ontology and the questions that are put to law. ${ }^{31}$ Within this framework the "world known in common and taken for granted" together with the framing of common sense and specialist knowledge, and the way the problem is devised, are all questioned. ${ }^{32}$ Indeed, Mr.Justice Holmes began this process of scrutiny from within:

"We are only at the beginning of a philosophical reaction, and of a reconsideration of the worth of doctrines which for the most part still are taken for granted without any deliberate, conscious, and systematic questioning of their grounds."

Heisenberg specifies this question thus:

"In so far as one can speak about scientific image of nature, one has to treat it not so much as an image of nature but rather as the image of our relationship with nature. ${ }^{334}$

The social theorist C.Wright Mills alluded to the essence of this reflexivity for the understanding of knowledge:

"Between consciousness and existence stand meanings and designs and communications which other men have passed on, first in human itself and later by the management of symbols. Those received and manipulated interpretations decisively influence such consciousness as men have of their existence." 35

\section{${ }^{30}$ Supra.n.8.}

${ }^{31}$ J.Freund, The Sociology of Max Weber (Penguin, 1972).

${ }^{32}$ C. Geertz, "Common Sense as a Cultural System" in Local Knowledge: Further Essays in Interpretative Anthropology (Basic Books, New York, 1983); H.Garfinkel, Studies in Ethnomethodology (Penguin, 1967); A.Schutz, The Phenomenology of the Social World (Heinemann Educational, 1972).

${ }^{33}$ Mr.Justice Holmes, "The Path of the Law" (1897) X Harv.L.Rev. 457.

${ }^{34}$ T.Shanin (ed.), The Rules of the Game (Tavistock, 1972).

${ }^{35}$ C.Wright Mills, Power Politics and People (O.U.P., 1964) at 405. 


\section{DENNING LAW JOURNAL}

These insights into the problem of reflexivity provide the basis for a critique of legal rules and the provocation problem.

\section{(b) Interpretative Reflexive Feminist Law.}

One of the most pressing tasks for the feminist legal critique is an analysis of legal rules and the implications of relevance, inclusions and exclusions for the female subject ${ }^{36}$ Such critique challenges the fallacy of law's gendered neutrality ${ }^{37}$ and confronts the masculinism of the "definitions, assumptions and ideals, and epistemological notions of a universal, objective rationality that underlie our legal system," ${ }^{38}$ exposing both the silencing, contortion and distortion of women's experience in law's constructs. ${ }^{39}$

Feminist legal criticism has demonstrated that law's universal objective rationality, the basis of legal doctrine, ${ }^{40}$ espoused in common law and precedent, merely transforms male experience into an "objective" doctrine that passes for the "normative" 41 and as reflecting all human experience. ${ }^{42}$ One of the more conspicuous ways this objective universal legality is constituted is within the

${ }^{36}$ E.Spelman, Inessential Woman: Problems of Exclusion in Feminist Thought (Beacon Press, Boston, 1988); J.L.Orff, "Demanding Justice without Truth: The Difficulty of Postmodern Feminist Legal Theory" (1995) 28 Loy.L.A.L.Rev.1197; S.Williams, "Feminist Legal Epistemology" (1993) 8 Berkeley Women's L.J. 63.

${ }^{37}$ S.L.R.Anleu, "Critiquing the Law: Themes and Dilemmas in Anglo-American Feminist Legal Theory" (1992) 19 Journal of Law and Society 423; N.R.Cahn, supra.n.1; R.Unikel, "Reasonable Doubts: A critique of the reasonable women standard in American Jurisprudence" (1992) 87 Nw.U.L.Rev. 326.

${ }^{38}$ L.Finley, "The Nature of Domination and the Nature of Women: Reflections on Feminism Unmodified" (1988) 82 Nw.U.L.Rev. 352

${ }^{39}$ E.M.Schneider, "Hearing Women not being heard: On Carol Gilligan's Getting Civilised and the complexity of voice" (1994) 63 Fordham L.Rev.33 at 34; M.J.Mossman, "Feminism and Legal Method: The difference it makes" (1986) 3 Australian Journal of Law and Society 30.

${ }^{40}$ V.Jackson, "Empiricism, Gender and legal pedagogy: An Experiment in a Federal Court Service at Georgetown University Law Center" (1994) 83 Geo.L.J. 461 at 472.

${ }^{41}$ J.E.Grbich, "The Body in Legal Theory" in M.A.Fineman \& N.S.Thomadsen (eds.), At the Boundaries of Law (Routledge, 1991) at 69.

${ }^{42}$ D.Nicolson, "Truth, Reason and Justice: Epistemology and Politics in Evidence Discourse" (1994) 57 M.L.R. 726 at 736. 


\section{BATTERED WOMEN - IN FEAR OF LUC'S SHADOW}

"reasonable man" construct, which occupies a centrifugal place in many branches of law, of particular relevance to the objective test in provocation, ${ }^{43}$ and of specific relevance to women's access to a defence of provocation. The resonance of the standard universal subject permeates beyond the "reasonable man" construct into rather more opaque expressions in the systemic ordering and hierarchy of legal knowledge. The distinction forged between common sense knowledge and expert opinion, the rules which circumscribe the entry or exclusion of this knowledge and the judicial interpretation of these rules are more invasive, determining what is deemed law or fact, what is material or immaterial, thereby fixing the lens of legal cognition. As Lacey, Wells and Meure recognise:
“..rules of evidence and procedure, crucial to the practical impact of criminal law, have been 'adjectival' and largely excluded from studies of criminal law. These rules set out what may or may not count as evidence, whom it may be given by and about, what form it may take, who may hear it, to what standard an issue must be proved and by whom, when an issue may be withdrawn or introduced." $" 44$

Common sense knowledge like the "reasonable man" standard is persuasively passed off like a camera obscura as the "immediate deliverance of experience, not deliberated reflections upon it." "45 Consider the basis of the remarks of Devlin, who writing of the common sense framework with reference to corroboration in sexual cases asserted: "[i]t may not be long before the ordinary juryman's and jurywoman's knowledge of sexual cases is sufficient to make a warning unnecessary.." ${ }^{46}$ By this he means that knowledge of women's predilection to make allegations of a sexual nature will become part of everyday common sense. What, however, is the nature of the knowledge to which he

${ }^{43}$ M.Minow, "Feminist Reason: Getting it and Losing it" (1988) 38 .Journal of Legal Education 47; N.R.Cahn, supra.n.1.

${ }^{44}$ Reconstructing Criminal Law (Weidenfeld, 1990) at 19-20; see also O'Donovan, supra.n.5 at 428.

${ }^{45}$ C.Geertz, supra.n. 32 at 75-77; R.H.Thompson, "Common Sense and Fact-Finding: Cultural Reason in Judicial Decisions" (1995) XIX Legal Siudies Forum 119 at 119.

${ }^{46}$ Supra.n.26 at 195. 


\section{DENNING LAW JOURNAL}

refers? This, he explains when he writes:

"A type of case in which a warning is required is that in which a charge of a sexual offence is made by a woman; these are sometimes due to sexual neuroses which can produce phantasies in which the woman half or even wholly believes. ${ }^{247}$

Here judicial subjectivism passes off and validates masculinist ideologies as common sense and really "what every one knows." This rule is now amended in the Criminal Justice and Public Order Act 1994 where:

"Any requirement whereby at a trial on indictment it is obligatory for the court to give the jury a warning about convicting the accused on the uncorroborated evidence of a person merely because that person is (a) an alleged accomplice of the accused, or (b) where the offence charged is a sexual offence, the person in respect of whom it is alleged to have been committed, is hereby abrogated."

\section{OF LEGAL RELEVANCE-BATTERED WOMAN EXPERIENCE}

In England and Wales battered women who kill their abusers have sought to admit evidence of this abuse on two levels. First as evidence of diminished responsibility, and secondly, as relevant at three junctures, to a defence of provocation.

(a) Battered Woman's Experience - "Expert" Knowledge.

The inclusion and admissibility of any knowledge, and its transfiguration into legal knowledge depends upon one of the main organising schemes of value reference in law - the distinction between fact and opinion. This distinction is assumed and unquestioned:

"It is as if the idea of distinguishing between fact and opinion was so overpowering in its logic that it simply fell from heaven into the

\footnotetext{
${ }^{47}$ Ibid. at 189.

${ }^{48}$ Section 32(1)(b).
} 


\section{BATTERED WOMEN - IN FEAR OF LUC'S SHADOW}

vacant heads of the judiciary. $\$ 49$

In truth, knowledge about the fact and nature of repeat violence and its "effects" on its recipients is neither common sense nor expert knowledge; instead it inhabits a hiatus between the two. Where this experience is considered relevant to state of mind- mens rea as in diminished responsibility, or relevant to a heightened perception of danger as in self-defence, or as a notional characteristic, introduction of this knowledge via the expert is admissible only if the defendant is considered to be suffering from some form of mental illness.

This limitation on admissibility of mental state evidence drives the knowledge about the battered woman's state of mind further into a therapeutic enclave, allowing only women who are prepared to acquiesce to the label of "mental illness," the opportunity to introduce such evidence. By contrast, the "male" excuse for violence, articulated in a defence of provocation, is constituted as common sense, avoiding the restriction placed on admissibility of mental illness evidence, or from binding the defendant in the mental illness straight-jacket necessary to a defence of diminished responsibility.

The leading case in interpreting the exclusionary rule, Tumer, ${ }^{50}$ established that expert evidence is only admissible if it is "to furnish the court with scientific information which is likely to be outside the experience and knowledge of a judge or jury," 51 excluding psychiatric or psychological evidence where the defendant is considered not to be suffering from a mental "illness." This rule has limited expert evidence to a defence of diminished responsibility.

In Turner, Lord Justice Lawton, excluded evidence which might have furthered the defence of provocation. The defence submission that "personality" i.e. that the defendant had a deep emotional involvement with the victim, which was likely to have caused an explosive rage after her confession to him that she had associated with other men, should be considered as a notional characteristic, was rejected by the court on the following grounds:

"We all know that both men and women who are deeply in love can, and sometimes do, have outbursts of blind rage when discovering unexpected wantonness on the part of their loved ones;

${ }^{49}$ Carol A.G. Jones, Expert Witness: Science, Medicine and the Practice of Law (Clarendon Press, 1994) at 6.

${ }^{50}[1975]$ Q.B.834.

${ }^{51}$ Ibid. at $841 \mathrm{D}$. 


\section{DENNING LAW JOURNAL}

the wife taken in adultery is the classic example of the application of the defence of 'provocation,' and when death or serious injury results, profound grief usually follows. Jurors do not need psychiatrists to tell them how ordinary folk who are not suffering from any mental illness are likely to react to the stresses and strains of life."

Concluding that "psychiatry has not yet become a satisfactory substitute for the common sense of juries," 53 Tapper notes "[t]he exclusion of opinion evidence on the ultimate issue can easily become something of a fetish." ${ }^{54}$ When it comes to the admissibility of expert evidence judges are diviners of law and fact, managing, organising, transfiguring and translating social into legal reality. This exclusionary rule has been applied inconsistently, ${ }^{55}$ condemning to a legal vacuum, evidence which is neither common sense nor satisfies the test demanded for admissibility of expert opinion. As Mackay and Colman accede ${ }^{56}$ judicial attempts to divide mental abnormality into conditions that require elucidation and those that do not has been unsatisfactory - "privileging certain types of discourse." 257

The inconsistencies in the application of the Turner rule can be illustrated by reference to confessional evidence where, the ad-hoc, case-by-case, nature of judicial divining is at its most capricious. In Weightman ${ }^{58}$ the defence was not permitted to call a psychiatrist who would have attested that the defendant "has an abnormality of personality, which can best be described as a histrionic personality disorder, characterised by emotional superficiality, impulsive behaviour when under stress and an impaired capacity to develop and sustain

${ }^{52}$ Ibid. at $841 \mathrm{G}$.

${ }^{53}$ Ibid at $843 \mathrm{~A}$.

${ }^{54}$ C.Tapper, Cross and Tapper on Evidence (8th.ed.,Butterworths, 1995) at 545.

${ }^{55}$ R.D.Mackay \& A.M.Colman, "Excluding Expert Evidence: a tale of ordinary folk and common experience" [1991] Crim.L.Rev. 800.

${ }^{56}$ Ibid. at 810 .

${ }^{57}$ C.Wells, "Battered Woman Syndrome and defences to homicide: where now?" (1994) 14 Legal Studies 266 at 270.

${ }^{58}$ (1991) 92 Cr.App.R. 291. 


\section{BATTERED WOMEN - IN FEAR OF LUC'S SHADOW}

deep or enduring relationships with other people" 59 in order to impugn the reliability of her confession to the killing of her daughter of two years of age. Indulging in hair-splitting discrimination, the defendant's abnormality of personality was said not to be mental "illness." Lord Justice McCowan stated:
"At the end of the day however it is very much a question of the facts in a particular case. It seems to us that the principle to be learnt from the cases, notably the case of Turner, is that a psychiatrist's evidence is inadmissible where its purpose is in effect to tell a jury how a person who is not suffering from mental illness is likely to react to the stresses and strains in life. The point taken here is that the appellant has an abnormal personality, as was conceded by Mr.Hunt for the prosecution at the trial. What does that abnormal personality amount to however? It seems to us that it is not something which is beyond the experience of normal non- medical people., ${ }^{\prime 0}$

Although in the case of $\mathrm{Ward},{ }^{61}$ where the defence submitted evidence that she was suffering from a "severe and deep rooted" ${ }^{62}$ personality disorder, it was held on appeal that expert medical evidence of a psychiatrist or psychologist was admissible at a criminal trial on the issue of whether what a defendant had said in a confession or admission was reliable, even where the defendant was held not to be suffering from mental illness, but suffering from a personality disorder described as a mental disorder. This principle derives from Toohey v. Metropolitan Police Commissioner" 63 " when a witness through physical (in which I include mental) disease or abnormality is not capable of giving a true reliable account to the jury, it must surely be allowable for medical science to reveal this vital hidden fact to them."

The court in Ward took the view that such evidence would have been

s9 Ibid at 293-294.

${ }^{60}$ Ibid.at 297.

${ }^{61}$ [1993] 2 All E.R.577.

${ }^{62}$ Ibid at $595 \mathrm{~g}$.

${ }^{63}[1965]$ A.C. 595.

${ }^{64}$ Ibid. per Lord Pearce at 608. 


\section{DENNING LAW JOURNAL}

admissible at the original trial had it been available, as it preceded Turner. Although in Raghip, Silcott \& Braithwaite, where Raghip had a low I.Q., the court took the view that such evidence could be admitted. ${ }^{65}$ It would appear that the courts have distinguished between those cases where medical evidence goes to the issue of confessional evidence, and those cases where evidence of mental illness goes to mens rea. Or is this decision merely left to judicial subjectivism, where:

"the principle of relevance is portrayed as no more than a conduit pipe for the application of whatever can be presented as reason, the exclusion of facts which might challenge the politics contained in substantive law can be represented, not as a political decision, but simply the neutral application of the principles of logic to the rules of substantive law.

In pleas of diminished responsibility and duress where women have attempted to rely on battered woman experience to explain their state of mind, the prosecution submit that battered women's evidence is not expert knowledge and thereby ensure its exclusion. An example of such a strategy, although unsuccessful, is found in Emery where the defendant was charged with occasioning actual bodily harm on a young child and failure to protect her child from her boyfriend's physical abuse. ${ }^{67}$ The defence was duress, and defending counsel applied to call two experts, a psychologist and a psychiatrist. The prosecution challenged the application submitting that the evidence to be admitted was common sense and did not require expert opinion to speak to it. Mr.Justice Astill, ruling the evidence admissible, said:

"There is potential expert evidence to the effect that if she is right, her will could have been crushed. That would afford her a good defence..Therefore, without further explanation or understanding, the jury's lack of understanding might lead to a guilty verdict, whereas if they were to consider the expert evidence which seeks to explain her conduct, they [might] find her not guilty. It follows from that that in my judgment the effects of abuse of the scale and

${ }^{65}$ The Times, 9th.December, 1991.

${ }^{66}$ D.Nicolson, supra.n.42.

${ }^{67}$ (1993) 14 Cr.App.R.(S) 394. 


\section{BATTERED WOMEN - IN FEAR OF LUC'S SHADOW}

persistence she describes might well not be within the capacity of a jury to understand unassisted by expert evidence. ${ }^{968}$

Mr.Justice Astill modified the Turner rule in respect of mens rea for duress to allow for admission of expert opinion in accordance with only one of the two criteria: that the knowledge to be admitted was "evidence which was complex and not known by the public at large"- thereby circumventing the second tortuous question of whether the mental abnormality of the defendant was one of mental "illness" or not. This modification is critical to the future inclusion of battered woman evidence in cases where that evidence may be said not to constitute a mental illness but a personality disorder.

\section{(b) Battered Woman Experience and provocation.}

Where the defence is one of provocation, battered woman experience has been relevant in three ways.

\section{(i) Cumulative Provocation}

First, battered woman experience is relevant to an understanding of the nature and history of the abuse, whereby the abused woman's common experience that domestic violence is not episodic, but repeated, persistent and escalating, are facts which have been admitted as legally relevant to the background circumstances as part of cumulative provocation. ${ }^{69}$ Such facts have been admitted as common sense and their admission sanctioned as relevant by the Court of Appeal in Thornton (No.2), ${ }^{70}$ reversing Mr.Justice Devlin's classic direction in Duffy that "[s]evere nervous exasperation or a long course of conduct causing suffering and anxiety are not by themselves sufficient to constitute provocation in law," 71 resolving inconsistency where in Fantle, ${ }^{72}$ the whole history was deemed relevant, whilst in Brown, ${ }^{73}$ the history was restricted to the morning of the killing. Lord Taylor asserted:

${ }^{68}$ Ibid.at 397.

${ }^{69}$ M.Wasik, "Cumulative Provocation and Domestic Killing" [1982] Crim.L.Rev. 29.

${ }^{70}$ Supra.n.8.

${ }^{71}$ [1949] 1 All E.R. 932.

72 [1959] Crim.L.Rev. 585.

${ }^{73}$ [1972] 2 All E.R. 1328. 


\section{DENNING LAW JOURNAL}

"The severity of such a syndrome and the extent to which it may have affected a particular defendant will no doubt vary and it is for the jury to consider ...it may form an important background to whatever triggered the actus reus. A jury may more readily find there was a sudden loss of control triggered by even a minor incident, if the defendant has endured abuse over a period, on the 'last straw' basis."74

Lord Goff in $L u c$ also reaffirms the relevance of cumulative provocation:

"Their Lordships wish to add, as a footnote, that it may be open to a defendant to establish provocation in circumstances in which the act of the deceased, though relatively unprovocative if taken in isolation, was the last of a series of acts which finally provoked the loss of self-control by the defendant and so precipitated his extreme reaction which led to the death of the deceased...Whether such a principle could successfully be invoked in cases such as, for example, the 'battered wife syndrome' is a matter upon which their Lordships can in the present case express no opinion, having heard no argument upon it, but must await a case in which the point arises for decision."

(ii) Perception and heightened awareness.

Secondly, on the question of the "effect" of violence on the abused woman there are two aspects to consider. The first aspect concerns the "effect" of repeat violence on the abused woman's heightened perception and specialist knowledge of the abuser's behaviour, which in turn shapes the abused woman's vigilance and strategy for survival. The effect of repeat violence on perception and anticipation of further violence is relevant to a defence of self-defence and provocation and to the "reasonableness" of the abused woman's response. Yet, efforts to assimilate the "effect" of the abuser's violence on the battered woman's "knowledge" of his behaviour and "perception" of likely harm or death, to thereby inform legal argument that self-defence is "reasonable in the

${ }^{74}$ See also supra.n. 8 at $1030 \mathrm{c}$.

${ }^{75}$ Supra.n. 10 at $1047 \mathrm{a}-\mathrm{c}$. 


\section{BATTERED WOMEN - IN FEAR OF LUC'S SHADOW}

circumstances" ${ }^{176}$ have been, thus far, unsuccessful. ${ }^{77}$ This is because the meaning of what is "reasonable" accords with, and is bound by, masculine experience and conventions. Hence there is the expectation of retreat, the use of proportionate force and a temporal proximity between the threat and use of violence, if selfdefence is to succeed. The battered woman's belief that she is in immediate danger, her perception of the temporal proximity of violence in the absence of "immediate" violence has been excluded as not "reasonable."

The meaning of imminent and immediate has been expanded to allow for accommodation of the battered woman's response as a prolonged and chronic rather than acute provocation. There has been an expansion of the understanding of temporal proximity time lapse from Mancini, ${ }^{78}$ whereupon the requirement was immediate to the morning of the killing, approved by the judge in Brown ${ }^{79}$ although unacceptable to the jury. Where trial judges have applied a more narrow approach the Court of Appeal is reticent to controvert although in many instances it is trial judges who have adopted a broader approach. The adherence to the Duffy ${ }^{80}$ formulation is undeniably curious given the wider formulation of "loss of self-control" facilitated in the Homicide Act 1957, ${ }^{81}$ and the common law, pre-Duffy, which was less concerned with "suddenness" and more concerned with whether the killing was motivated by revenge. ${ }^{82}$ Lord Chief Justice Taylor, in Ahluwalia explains that, whilst a delayed reaction would not necessarily defeat a defence of provocation "..the longer the delay and the stronger the evidence of deliberation on the part of the defendant, the more likely

${ }^{76}$ Criminal Law Act 1967 s.3(1) - "A person may use such force as is reasonable in the circumstances in the prevention of crime, or in effecting or assisting in the lawful arrest of offenders or suspected offenders, or of persons unlawfully at large."

" See Rossiter (1992) 95 Cr.App.R. 326; Gardiner The Independent 30th.October, 1992; Oatridge (1991) 94 Cr.App.R. 367; Line The Daily Telegraph 4th.February, 1992; Hobson supra.n.14.

${ }^{78}$ Mancini v. D.P.P. [1942] A.C. 1.

${ }^{79}$ Supra.n.73 at 1333.

${ }^{80}$ Supra.n.71.

${ }^{81}$ Section 3

${ }^{82}$ (1833) 6 C. \& P. 157 


\section{DENNING LAW JOURNAL}

it will be that the prosecution will negative provocation." ${ }^{83}$ In Ahluwalia, ${ }^{84}$ it is clear that a new meaning is attached to the phrase "sudden and temporary" switching the focus away from the earlier decided meaning of the proximity in time between the last act of provocation and the retaliation as articulated in Mancini, ${ }^{85}$ to embrace a meaning of "sudden" which instead enlarges on the nature and character of the reaction, which incidentally is more consonant with the literal meaning of the word "sudden." Indeed Smith and Hogan write:

"It seems that the words 'sudden and temporary,' imply only that the act must not be pre-meditated. It is the loss of control which must be 'sudden,' which does not mean 'immediate""86

Whilst this development is novel for the Court of Appeal, trial judges, whose reasoning is less conspicuous, have often retreated from the Duffy formulation placing a greater emphasis on the quality and nature of the response. ${ }^{87}$ Furthermore, there have been limitations placed on the nature of the reaction which has relied on a physical manifestation of anger, rage and passion, ${ }^{88}$ whereas it is a state of despair, anxiety and trauma which more correctly characterises the abused woman's experience of loss of self-control.

(iii) A vexed question - battered women's experience as a notional characteristic. The third juncture at which battered women's experience is of relevance concerns the "effect" repetitive violence, including living in continuous fear of further violence, has on mental well-being focussing on anxiety, depression and post traumatic stress and the possible effect on mens rea. It is here that the experience of the battered woman may or may not result in "battered woman syndrome." This appreciation of the effect of violence and fear of violence on

${ }^{83}$ Supra.n. 19 at 896d.

${ }^{84}$ Supra.n. 19.

${ }^{85}$ Supra.n.78 at 9 .

${ }^{86}$ J.C.Smith \& B.Hogan, Smith and Hogan on Criminal Law: Cases and Materials (6th.ed., Butterworths, 1996) at 365.

${ }^{87}$ See A.Ashworth, "Sentencing in Provocation Cases" [1975] Crim.L.Rev. 552 at 557-

${ }^{88}$ J.Horder, supra.n.6. 


\section{BATTERED WOMEN - IN FEAR OF LUC'S SHADOW}

mental and physical state has followed on psychological advances identifying and defining a specific condition of "battered woman's syndrome" experienced by victims of repeat abuse. It is with respect to the mental and physical health of abused women that attention has focused both in the clinical and legal setting. In the clinical setting the concern has been to treat the fear, anxiety and trauma of the battered woman, whilst within the legal setting the concern has been to determine whether the battered woman has a lowered threshold of self-control, and if so, whether this should be considered relevant to mens rea. Within the clinical arena there is no universal agreement on the nature of the condition, although since 1994 it has been recognised as a mental illness within the British classification of mental diseases. ${ }^{89}$ Nevertheless, without a more certain symptomatology, diagnosis and prognosis, women's experiences of the effects of battering, encounter difficulties in being used to assess responsibility (mens rea). At the same time, attempts to formulate the "condition" in scientific terms have severely limited its use and accessibility to only those women who display the required symptomatology. Walker, from whose work understanding of the condition originally derives, describes helplessness, fear, trauma and entrapment. ${ }^{90}$ Criticised by feminist psychologists, and controverted by prosecutors, the "syndrome", so-called, it is argued wrongly connotes a mens rea which goes towards explaining why women who are battered cannot leave violent men, rather than explaining the necessity of the last act in their efforts at survival.

Evidence of battered woman syndrome has constituted a notional characteristic of the objective test in provocation, if it is of the necessary degree of permanence. ${ }^{91}$ Lord Chief Justice Taylor explains:

"..depending on the medical evidence, the syndrome may have affected the defendant's personality so as to constitute a significant characteristic..."92

${ }^{89}$ See supra.n. 14.

${ }^{90}$ L.Walker, Terrifying Love: When the Battered Woman Kills (Harper and Row, New York, 1989).

${ }^{91}$ Supra.n.19 at 898 a.

${ }^{92}$ Supra.n. 8 at $1030 \mathrm{~d}$. 


\section{DENNING LAW JOURNAL}

Lord Chief Justice Taylor in Ahluwalia,${ }^{93}$ in responding to Geoffrey Robertson's ground of appeal, that the defendant was suffering from battered woman syndrome, such that it had "become a characteristic within the meaning of Lord Diplock's formulation," 94 intimated that if battered woman syndrome evidence had been admitted at the original trial, or indeed evidence of any other specific condition, which could amount to a characteristic, "different considerations may have applied," 95 and thus de facto authenticated the battered woman "syndrome" as a notional characteristic. The idea of a notional characteristic embracing mental state/personality was further developed by Lord Chief Justice Taylor in Dryden, ${ }^{96}$ where he concluded that "the obsessiveness on the part of the appellant and his eccentric character" ${ }^{97}$ was a characteristic. Lord Justice Hirst adopted a similar approach in Humphreys, ${ }^{98}$ and declared a personality with "immature and explosive and attention seeking traits," ${ }^{99}$ even though these traits did not form part of the gravity of the provocation expressly, consistent with the "reasonable man" standard. He added:
"[T]he jury would, as ever, use their collective common sense to determine whether the provocation was sufficient to make a person of reasonable self-control in the totality of the circumstances (including personal characteristics) act as the defendant did."

Neither Lord Chief Justice Taylor nor Lord Justice Hirst differentiated between characteristics which formed part of a personality which was predisposed to loss of self-control and characteristics which were manifest features of the individual and specifically referred to by the provocation. The judge must give directions to the jury on both objective and subjective tests indicating what evidence including relevant characteristics might be capable of amounting to provocation

${ }^{93}$ Supra.n. 19 at $898 \mathrm{e}$.

${ }^{94} \mathrm{Ibid}$. at $897 \mathrm{~d}$.

${ }^{95}$ Ibid. at $898 \mathrm{f}$.

${ }^{96}$ [1995] 4 All E.R. 987.

${ }^{97}$ Ibid. at $998 \mathrm{~d}$.

${ }^{98}$ Supra.n.29.

${ }^{99}$ Ibid.at 1012 d. 


\section{BATTERED WOMEN - IN FEAR OF LUC'S SHADOW}

(per Lord Goff in Morhall). ${ }^{100}$ Lord Justice Stuart-Smith in Stewart, stated:

"In our judgment, where the judge must, as a matter of law, leave the issue of provocation to the jury, he should indicate to them, unless it is obvious, what evidence might support the conclusion that the appellant lost his self-control."101

This suggests that judges must consider, where relevant, instructing the jury to consider battered woman syndrome as a notional characteristic, as well as indicating to them evidence pointing to loss of self-control, thereby divining further what is and what is not relevant.

There has been some guidance on the battered woman syndrome as a notional characteristic. Lord Chief Justice Taylor, in placing limits on the expansion of a mental state as a notional characteristic in Dryden, asserted:

"In our opinion it is not enough to constitute a characteristic that the offender should merely in some general way be mentally deficient or weak minded." 102

However it seems clear that battered woman syndrome cannot be classified as a mental deficiency or weak mindedness. Following the judgment of the Privy Council in Luc Thiet Thuan v. R., ${ }^{103}$ the untested status of battered woman syndrome evidence as a notional characteristic is thrown further into question. Here, the defendant appealed against a conviction for the murder of his former girlfriend, who had sustained multiple stab wounds consistent with defensive wounds, on the ground that the trial judge had wrongly rejected the defence submission that evidence of a medical condition - a form of "organic brain dysfunction" that left him with a difficulty in controlling an impulse - as relevant to provocation. Lord Goff delivering the majority judgment of the Board (Lord Steyn dissenting) rejecting this ground of appeal, declared the recent expansion

${ }^{100}$ Supra.n. 9 at 668.

${ }^{101}$ [1995] 4 All E.R. 999 at 1007a.

102 Supra.n.94 at $997 \mathrm{j}$.

${ }^{103}$ Supra.n. 10. 


\section{DENNING LAW JOURNAL}

of the notional characteristic principle in Ahluwalia, ${ }^{104}$ Humphreys ${ }^{105}$ and Dryden ${ }^{106}$ and by extension, Thornton (No.2), ${ }^{107}$ to be wrong:

"But it is an entirely different question whether the mental infirmity of the defendant which impairs his power of self-control should be taken into account; and indeed it is difficult to see how it can be consistent with a person having the power of self-control of an ordinary person."

Lord Goff following his earlier reasoning in Morhall, ${ }^{109}$ was critical of those who had followed McGregor, ${ }^{110}$ and those who, in recent cases such as Newell, ${ }^{111}$ had taken the view that the characteristic might be a more transitory phenomenon. In Morhall he asserted:

"At all events it follows that, in a case such as the present, a distinction may have to be drawn between two different situations. The first occurs where the defendant is taunted with his addiction (for example, that he is an alcoholic, or a drug addict, or a glue sniffer), or even with having been intoxicated (from any cause) on some previous occasion. In such a case, however discreditable such a condition may be, it may where relevant be taken into account as going to the gravity of the provocation. The second is the simple fact of the defendant being intoxicated - being drunk, or high with drugs or glue - at the relevant time, which may not be so taken into account, because that, like displays of lack of ordinary self-control,

\footnotetext{
${ }^{104}$ Supra.n. 19.

${ }^{105}$ Supra.n.29.

${ }^{106}$ Supra.n.94.

${ }^{107}$ Supra.n.8.

${ }^{108}$ Supra.n. 10 at $1041 \mathrm{~b}$

${ }^{109}$ Supra.n. 9 at $659 \& 667 \mathrm{e}-\mathrm{f}$.

${ }^{110}[1962]$ N.Z.L.R. 1069 .

111 (1980) 71 Cr.App.R.331.
} 


\section{BATTERED WOMEN - IN FEAR OF LUC'S SHADOW}

is excluded as a matter of policy." 112

He argued that the meaning of English statute could not be derived from $M c G r e g o r^{113}$ and, secondly, that the New Zealand case law in McCarthy ${ }^{114}$ had trenchantly critiqued and disapproved of the earlier approach taken in McGregor upon which the cases of Taaka, ${ }^{115}$ and Leilua ${ }^{116}$ had relied. Lord Goff argued that this reasoning had resulted in an "unhappy influence" 117 on the development of English case law, in the cases of Ahluwalia, ${ }^{118}$ Dryden $^{119}$ and Humphreys ${ }^{120}$ especially. Indeed as Lord Chief Justice Taylor asserts in Dryden "21 _ [w] hat characteristics are appropriate for the jury to consider has been a vexed question since Camplin." In Luc, ${ }^{122}$ Lord Goff returned to his reasoning in Morhall, ${ }^{123}$ where he had distinguished between those cases where loss of self-control is the result of provocation which is directed at the characteristic and where loss of self-control is not specifically the result of provocation being directed at that characteristic, relying on the earlier argument of Ashworth, who asserted:

"The proper distinction ..is that individual peculiarities which bear on the gravity of the provocation should be taken into account, whereas individual peculiarities bearing on the accused's level of

${ }^{112}$ Supra.n.9 at 667e-f.

${ }^{113}$ Supra.n. 110.

114 [1992] 2 N.Z.L.R. 550.

${ }^{115}$ [1982] 1 N.Z.L.R. 198.

${ }^{116}[1986]$ N.Z.Recent Law 118.

${ }^{117}$ Supra.n. 10 at 1044 c.

${ }^{118}$ Supra.n.19.

${ }^{119}$ Supra.n. 94.

${ }^{120}$ Supra.n. 29.

${ }^{121}$ Supra.n.94 at $997 \mathbf{a}$.

${ }^{122}$ Supra.n.10 at $1044 \mathrm{f}$.

${ }^{123}$ Supra.n.9. 


\section{DENNING LAW JOURNAL}

self-control should not."124

His consideration of Ashworth goes considerably beyond the now permitted reference to parliamentary debates in pursuit of the interpretation of statute (cf. Pepper v. Hart ${ }^{125}$ ) maligned earlier in Davis v. Johnson. ${ }^{126}$

Lord Goff asserted that it would very rarely be necessary to explain this distinction to the jury presumably because they would understand it. ${ }^{127}$ It is suggested that this fails to consider the following point. Whilst an example of where the notional characteristic was affected by the gravity of the provocation would be provided where, for example, a man with an exceptionally large nose is taunted about it, and an example of the notional characteristic provided by the loss of self-control would be provided by a man claiming provocation because of over-sensitivity, or an inability to control a temper, it is rarely ever the case that this distinction presents itself so clearly distinguished and caricatured.

Indeed on this point Lord Steyn in $L u c^{128}$ found that there was no such spurious and artificial and restrictive rule which excluded from consideration characteristics which went to loss of self-control - "[i]n my view a jury would be rather puzzled by such artificially compartmentalised direction."129

The accommodation of notional characteristics of the accused has softened the objective test in order to allow for consideration of the impact of provocation on one especially predisposed to a specific provocation. Case law indicates that whilst an excitable personality or quick temper cannot rely on provocation, ${ }^{130}$ it would be difficult to see how a battered woman who was being abused could not rely on this feature as a notional characteristic since the provocation if not expressly, then impliedly, goes to the characteristic. The battered woman is targeted repeatedly by her abuser precisely because she is a battered woman. It is argued here that the battered woman characteristic also goes to the loss of self-

${ }^{124}$ A.Ashworth, "The Doctrine of Provocation" [1976] C.L.J. 292 at 299.

${ }^{125}$ [1993] 1 All E.R. 42 (H.L.).

${ }^{126}$ [1979] A.C. 264.

${ }^{127}$ Supra.n.10.

${ }^{128}$ Ibid. at $1048 \mathrm{~g}$.

${ }^{129}$ Ibid at $1049 \mathrm{~g}$.

${ }^{130}$ Supra.n.16. 


\section{BATTERED WOMEN - IN FEAR OF LUC'S SHADOW}

control, since the fact of being repeatedly battered alters and effects her perception of her abuser and her response to what the non-battered woman may only consider slight provocation. Simply the battered woman knows of what the abuser is capable!

It seems that Lord Goff's reasoning and close inspection derives from a repugnance with the alternative outcome in $L u c,{ }^{131}$ if the notional characteristics were to be accommodated. Indeed Lord Chief Justice Taylor had earlier in Morhall, ${ }^{132}$ resisted Lord Goff's reasoning on similar grounds of repugnance:

“..logic would demand similar indulgence towards an alcoholic, or a defendant who had illegally abused heroin, cocaine, or crack to the point of addiction. Similarly, a paedophile, upbraided for molesting children, would be entitled to have his character weighed in his favour on the issue of provocation"133

Lord Steyn argued that the purpose of the courts is to work out "sensible and just solutions," 134 arguing for the relevance of personality disorder affecting selfcontrol on the basis that:

"The view of the law contended for by the prosecution will inevitably lead to injustice. It will result in convictions of murder and mandatory life sentences in cases where that is wholly inappropriate. In my view our law does not compel such crude and unfair results." $" 135$

He concluded that the decisions in Ahluwalia and Dryden are the expressions of the dictates of justice over the prompting of legal logic. ${ }^{136}$ "In the meantime nobody should underestimate the capacity of our law to move forward where

${ }^{131}$ Supra.n. 10.

${ }^{132}$ Supra.n.9.

${ }^{133}$ Ibid. at $663 \mathrm{~b}$.

${ }^{134}$ Supra.n. 10 at 1051 a.

${ }^{135}$ Ibid. at $1049 \mathrm{~g}$.

${ }^{136}$ Ibid. at $1055 \mathrm{~d}-n . b$. Lord Steyn supported Lord Goff's opinion in Morhall. 


\section{DENNING LAW JOURNAL}

necessary, putting an end to demonstrable unfairness exposed by experience,"137 - an allegiant to the way opened and the path shown by Lord Chief Justice Taylor, a dynamic and creative law-maker and man of justice.

\section{WALKING IN THE SHADOW OF LUC.}

The authority of the Privy Council in Luc of course is not absolute, although Smith and Hogan argue:
"Decisions of the Privy Council are not binding on English courts; but when the Board consists of five Lords of Appeal and may be thought to represent the opinion of the House of Lords, it can hardly be ignored"138

In any event, whatever the status of $L u c$, the reasoning replicates that hitherto developed by the House of Lords in Morhall, whilst the Court of Appeal in Parker ${ }^{139}$ has refused to follow Luc, although the grounds for dissension, whether in whole, or in part, were not explicated. Justice for battered women who kill, continues to be cloaked in the shadow of Luc and Morhall. Recent case management in cases involving battered women who kill, post- $L u c$, reflects a predilection towards a defence of diminished responsibility in order to avoid inviting the prosecution challenges that would inevitably flow from the reasoning in $L u c$, as the following cases strongly suggest.

\section{(a) The Thornton Retrial - diminished responsibility and provocation.}

The retrial of Sarah Thornton at Oxford Crown Court on 13th. May, 1996 was expected to rely on fresh evidence relating to battered woman syndrome. Such evidence was not to play any part, whether as an element of psychiatric evidence and therefore expert opinion under the limb of the defence of diminished responsibility, or as a characteristic of the "reasonable man" under the limb of the objective test of provocation. Pleading diminished responsibility and provocation together, the boundaries of reasonableness and unreasonableness,

${ }^{137}$ Ibid. at $1055 \mathrm{~g}$.

${ }^{138}$ Supra.n.85 at 432.

${ }^{139}$ Supra.n.11. 


\section{BATTERED WOMEN - IN FEAR OF LUC'S SHADOW}

common sense knowledge and expert opinion were deliberately blurred. So too was the burden of proof - on the defence to prove diminished responsibility on the balance of probabilities, and in provocation on the prosecution to prove beyond all reasonable doubt that the case was not one of provocation. It was perhaps an understandable strategy, since at the pre-trial conference preceding the original trial, that lack of intent - involuntary manslaughter - unlawful and dangerous act- provocation - diminished responsibility - were all canvassed. ${ }^{140}$ At that first trial, Thornton pleaded diminished responsibility, the jury considered the medical evidence insufficient, or not such as to impair substantially her responsibility. Counsel did not rely on provocation, although it was a defence put to the jury by the judge and similarly rejected by them. An appeal was won on the ground that battered woman syndrome had not been properly considered by the judge as a notional characteristic of the accused. On retrial, the mainstay of the defence argument was evidence of cumulative provocation - that of a chronic alcoholic husband who was on occasion violent on a person suffering from an abnormality of mind. This in turn was considered for its impact on an "alcoholic's wife," which it was submitted constituted a notional characteristic. Dr.Glatt, in written evidence, delineated the characteristics of an alcoholic's wife:

"gradually worn out by emotional strain and stress, living on the edge of a volcano - such a wife might frequently lose her selfcontrol which might snap suddenly when something for her may become the last straw any reasonable wife would be affected."141 Defence counsel, Michael Mansfield Q.C., presented the culmination of this as - "[i]t's the snap, it's a bridge too far, a straw too much." 142 The defendant's evidence to establish diminished responsibility was evidence of an histrionic disorder, including attempts at suicide, being found walking naked by police in Withington, Manchester, clutching a teddy-bear, the latter incident resulting in admission to hospital under the Mental Health Act 1983. Thornton, it was said, satisfied the criteria of someone suffering from post traumatic stress disorder. It was unclear whether this post traumatic stress disorder was to form a part of the

${ }^{140}$ Supra.n.27 at $311 \mathrm{j}$.

${ }^{141}$ Supra.n.12.

${ }^{142}$ Ibid. 


\section{DENNING LAW JOURNAL}

diminished responsibility, and thereby requiring experts to speak to it, or a notional characteristic and part of a defence of provocation, and thereby common sense knowledge following the Turner rule. Summing-up Michael Mansfield said:

"You have a sense of the pressures - a pressure cooker .. we have a complicated situation - living with an alcoholic and having a disordered personality."

In redirecting the jury on provocation, Mr.Justice Scott Baker said:

"Provocation is a single act or a series of acts done or words said or a combination of both which causes in the defendant a sudden and temporary loss of self-control which would cause a reasonable person to lose self-control and behave as the defendant did.

Provocation may have been such that it caused a temporary loss of self-control and at that time not being master of his mind. It is not enough to be made angry or smouldering resentment or revenge."

Elaborating further on what factors might constitute characteristics, he asked the jury to consider whether she was -

"unable to control herself ...unable to stop.. whatever provoked the defendant to lose her self-control must have made an ordinary reasonable and sober woman in the same position as the defendant react as the defendant did affecting the gravity to her.. an ordinary reasonable person with such characteristics. The characteristics you may consider are the defendant's personality disorder and the background of living with Malcolm Thornton, an alcoholic, and the domestic circumstances between them, that is whatever she had to put up with before.. you are entitled to look at previous conduct that the deceased was an alcoholic."144

Psychiatric evidence submitted on behalf of the prosecution sought to demolish any suggestion that she was suffering from battered woman syndrome pointing 


\section{BATTERED WOMEN - IN FEAR OF LUC'S SHADOW}

out that she did not fit the stereotype:

"She appears resourceful and determined rather than in deep despair. There is no evidence that she has lost self-respect or esteem or given up in despair. It is not a picture of a person who is seriously anxious, depressed, nor self-loathing."

It is particularly this limitation which has so often been fatal to adducing battered woman syndrome as a defence. Two psychiatrists for the defence gave evidence that she suffered from a mental disorder which they considered "equivalent" to battered woman syndrome. Acquitting her of murder and convicting her of manslaughter, Mr.Justice Scott Baker sentenced Thornton to a term of five years' imprisonment, which she had already served, on the basis, not of provocation, but of diminished responsibility! ${ }^{145}$

The inability of many battered women to fit the passive victim stereotype of the syndrome has constituted a key obstacle to its admissibility in the U.S.(see United States v. Wilson ${ }^{146}$ \& United States v. Whitetail ${ }^{147}$ ) as well as in England and Wales as the Thornton cases suggest. There has been, however, some limited expansion of the characteristics of the syndrome to allow for the admissibility of battered woman syndrome in cases where women are resourceful and not passive - see for example Bennett (No.2). ${ }^{148}$ There are further objections to the admission of battered woman syndrome under a diminished responsibility defence where the syndrome creates a "pathological cul-de-sac" for women, ${ }^{149}$ shifting the vortex away from the reasonableness of the defendant's action onto the unreasonableness and abnormality of her state of mind. The decision in the Thornton retrial, not to rely on battered woman syndrome is indicative of the defence's anticipation of the pitfalls of fitting the syndrome typology in its entirety to the defendant, together with the difficulties in arguing battered woman syndrome as a notional characteristic under provocation.

${ }^{145}$ S.S.M.Edwards \& C.Walsh, "The Justice of Retrial" (1996) 146 N.L.J. 857.

${ }^{146}$ 2nd.February, 1993 Lexis Transcript No.4584.

${ }^{147} 956$ F.2d.857 (1992).

${ }^{148}$ O.J.No.892 cited in E.Sheehy, "Battered Woman Syndrome: Developments in Canadian Law After R.v. Lavallee" in Women, Male Violence and the Law edited by J.Stubbs, The Institute of Criminology Monograph Series No.6, Sydney, Australia.

${ }^{149}$ H.Kennedy, Eve Was Framed (Chatto and Windus, 1992) at 94. 


\section{DENNING LAW JOURNAL}

(b) Sangha - More abuse but more diminished responsibility.

Again the shadow of $L u c$ casts its silhouette on trial management in the case of Sangh $a^{150}$ where a provocation defence might well have been the strategy preLuc. In Sangha a battered wife killed an abusive and adulterous husband, and also tried to kill herself. Her defence was one of diminished responsibility. The facts suggest clearly that a defence of provocation would have been available and certainly preferable, given that the battered woman defendant does not see herself as mentally ill, but sees her actions as reasonable. However, given the debate which has bifurcated the evolution of the notional characteristic into those characteristics which go to the gravity of the provocation and those which go to the loss of self-control, only the former being legitimate, undeniably the safer strategy is a defence of diminished responsibility.

"Mr.Singh has described the catalogue of mental and physical cruelty and abuse to which the appellant was exposed by her husband over a period of more than 20 years of marriage. It is summarised as having included regular violence between 1975 and 1990. Incidents involved her being punched, kicked, almost strangled, struck with a walking stick and with a pan, beaten whilst she was pregnant and beaten in front of her parents. It is said that her husband showed her no love, care or affection but, on the contrary, was liable to force physical sex upon her without her consent. He would sulk and refuse to speak to her for periods of days or even weeks. He took from her all that she earned and used her wages for his own purposes or, on occasion, to send to his own family abroad. He made degrading comments of a sexual nature to the appellant and even to her sister. He drank regularly to excess, either in the house or by staying out late for the purpose. He would mock her religious beliefs. An example of that was intentionally using her pans to cook meat despite the fact that for religious reasons she is herself a vegetarian. He showed (and this is important) violence to his children from time to time. In October, 1990 he beat two of his three daughters over the head with a hockey stick, as a result of which they were bruised, and the consequence of that ultimately was that all three daughters, to the great distress of the appellant, were taken into care. For that offence the husband was convicted of assault occasioning actual bodily harm. Although

${ }^{150}$ Supra.n.13. 


\section{BATTERED WOMEN - IN FEAR OF LUC'S SHADOW}

physical violence to the appellant evidently ceased after 1990 , it continued in relation to the children. On one occasion the thrashing of one of the sons left him black and blue, and on another occasion drew blood. We have already described the extent of the work that both at home and in the course of her employment was carried out by the appellant. It is said on her behalf that the cumulative effect on her was very damaging. She coped for long periods but would from time to time become distraught and depressed. That resulted in five separate occasions over the years on which she attempted to take her own life. They showed a desperate and depressed woman who, as it is said on her behalf, could see no way out of her plight."151

The defence strategy might well have been that of provocation although in the light of Morhall/Luc the outcome of a provocation defence was less predictable than that of a defence of diminished responsibility.

\section{(c) Hobson - U-tums - battered woman experience as diminished responsibility.}

Luc similarly cast a shadow in the appeal of Kathleen Hobson against her murder conviction on 19th.October, 1992 at Liverpool Crown Court. ${ }^{152}$ Hobson stabbed and killed her abusive and alcoholic partner. Her defence of self-defence failed. There had been a history of violence. At the first trial, no evidence of battered woman syndrome had been admitted. The grounds for appeal were that at the time she was suffering from battered woman syndrome and would have therefore pleaded diminished responsibility. Helena Kennedy Q.C., counsel for Hobson, did not argue on appeal, (as well might have been the case before $L u c$ ) that a defence of provocation had not been adequately put by the judge as an alternative to self-defence, or that battered woman syndrome was relevant to a defence of provocation. The facts clearly indicated a history of violence and evidence of cumulative provocation. The appellant had endured considerable violence at the hands of the deceased over some 18 months prior to the offence, she had called the police on some 30 previous occasions, making formal complaints on four orcasions. The evidence of two psychiatrists, Dr.Mezey and Dr.Ghosh, was that Hobson was suffering at the time from battered woman syndrome, although it was not at the time of the original trial recognised as a

${ }^{151}$ Ibid.

${ }^{152}$ Supra.n. 14. 


\section{DENNING LAW JOURNAL}

mental illness.

"It was not until 1994 that Battered Womens' Syndrome was included in the standard British classification of mental diseases, although, prior to that date, it had been included in the American classification. In consequence, at the time of the appellant's trial in 1992 it would not have been a condition which would have been readily considered by practising British psychiatrists, save the relatively small number who had a particular experience and expertise in relation to that condition. Battered Womens' Syndrome is a variant of post-traumatic stress disorder."

It was also added - "that that condition, if it existed at the relevant time, was material to the defendant's characteristics when they fell to be considered in relation to the defence of provocation under s.3 of the Act." Mr.Riordon Q.C., for the prosecution, whilst accepting the existence of battered woman syndrome and its relevance to diminished responsibility, argued that the symptoms she had were not of a degree which would give rise to an abnormality of mind, such as to sustain a defence of diminished responsibility. A retrial was ordered.

\section{A LEGAL PROSTHETIC?}

Whichever way the experience of battered women is legally reconstituted in the future - either as a notional characteristic or as an abnormal mental state - it remains a precarious appendix to a systemic masculinist law. How can the feminist challenge to law advance when the systemic organisation of law's fabric remains masculinist? In the United States there have been some successes in challenging law's frame of reference. The "Wanrow jury instruction" ${ }^{153}$ is a product of a recognition that the standard universal subject speaks exclusively of men. The court in granting Wanrow a retrial held that the defendant's actions are to be judged against her own subjective impressions and not those which a detached jury might determine to be objectively reasonable. ${ }^{154}$ Other attempts to address the genderism of legal rules on the basis that a rule in respect of modus operandi may not be applicable to women, is provided in Easterling v. State, where the defendant was grabbed by the hair, beaten and choked by the

${ }^{153} 559$ P.2d.548 (1977).

${ }^{154}$ Ibid, at 558 . 


\section{BATTERED WOMEN - IN FEAR OF LUC'S SHADOW}

deceased. ${ }^{155}$ She then stabbed him. The court, on appeal, recognised that particular physical attributes of a defendant might justify her use of a dangerous weapon to repel an unarmed attacker. In Ellison v. Brady, a nominally feminist "reasonable woman" standard was adopted for sexual harassment in the workplace. ${ }^{156}$ In Andrews v. City of Philadelphia two female police officers who were subjected to derogatory name calling and pornography at work, had their complaint assessed in accordance with a "reasonable woman" standard, a work environment hostile and offensive to women of reasonable sensitiveness. ${ }^{157}$

However, merely adding women to law ${ }^{158}$ to accommodate battered women's experience has been widely argued to be incapable of resolving the problem. ${ }^{159}$ Women's experiences are either excluded or, if included, are hardly recognisable, reconstituted and transfigured by law, these experiences must fit within pre-existing frameworks, rules and conventions. This means that the woman in fear of her life who acts in self-defence surviving in the shadow of Luc must plead diminished responsibility however mismatched. Thus the lack of synchronicity between women's experiences and the way in which law includes and thereby misframes them continues. It is not possible to skin the law of its masculinism, nor is it enough to engage in grafting women on through some politically cosmetic prosthesis solution, the morphology and ontology of law must continue to be confronted immediately and the artificiality of rules and relevances such as the "rule" in $L u c$ resisted.

${ }^{155} 267$ P.2d 185 (1954)

${ }^{156} 924$ F.2d 872 (9th.Cir., 1991) at 878

${ }^{157} 895$ F.2d. 1469 at $1480 \& 1481$ (1990).

${ }^{158}$ C. Smart, Feminism and the Power of Law (Routledge, 1989) at 66.

${ }^{159}$ Supra.n.57 at 275. 